\title{
Modified steel basket technique for the treatment of equine cervical vertebral stenotic myelopathy - a case report
}

\section{Modificação da técnica do cesto de aço para tratamento de mielopatia estenótica cervical em equino - relato de caso}

\author{
Frederico Fernandes Araújo $^{1 *}$; Monalisa Lukascek de Castro ${ }^{1}$; \\ Luciane Maria Laskoski ${ }^{1}$; Mariana Pavelski ${ }^{1}$; Ivan Deconto²; \\ Peterson Triches Dornbusch ${ }^{2}$
}

\begin{abstract}
Cervical vertebral stenotic myelopathy (CVSM), also known as cervical ataxia or wobbler syndrome, is caused by the narrowing of the medullary canal due to a malformation of the cervical vertebrae, resulting in compression of the spinal cord and neurological alterations such as ataxia, hypermetria, weakness, and abnormal stance. The treatment options can be conservative or surgical, with varied effectiveness. The most appropriate surgical technique in the majority of cases is arthrodesis, providing quick and efficient decompression of the spinal cord. The goal of this case report is to present an equine patient with CVSM that was surgically treated using a new modified cage model. The diagnosis was based on history, clinical signs and radiographic evidence of spinal cord compression between the $\mathrm{C} 3$ and $\mathrm{C} 4$ vertebrae, after ruling out possible infectious agents. The surgical procedure for the decompression and stabilization of the point of stenosis was performed using a modified Cloward's technique and a new cage model fixed with two screws. Evidence of fusion was obtained by periodic radiographs over six months of postoperative care. The new cage model used in this surgery proved to be efficient for the decompression and stabilization of the vertebrae, allowing arthrodesis development and remission of the clinical signs. Fixation of the cage with screws reduces the risk of migration of the implant.
\end{abstract}

Key words: Horse, medullary compression, spine surgery, steel cage, wobbler

\section{Resumo}

A mielopatia estenótica cervical (MEC), também conhecida com ataxia cervical ou síndrome de Wobbler, é causada por um estreitamento do canal vertebral devido à malformação das vertebrais cervicais, resultando em uma compressão da medula espinhal e alterações neurológicas como ataxia, fraqueza e postura anormal. As opções de tratamento podem ser conservador ou cirúrgico, sendo que ambos apresentam eficácia variável. A técnica cirúrgica mais apropriada para a maioria dos casos é a artrodese, promovendo rápida e eficiente descompressão da medula espinhal. O objetivo deste trabalho é relatar o caso de um equino com MEC que foi tratado cirurgicamente aplicando-se uma técnica modificada com um novo tipo de cesto metálico. O diagnóstico foi realizado por meio do histórico, sinais clínicos e evidências radiográficas de compressão medular entre as vértebras C3 e C4, após descartar possíveis agentes infecciosos. O procedimento cirúrgico para descompressão e estabilização do ponto de estenose foi realizado utilizando-se a técnica modificada de Cloward e um novo modelo de

\footnotetext{
${ }^{1}$ Discentes de Pós-Graduação, Universidade Federal do Paraná, UFPR, Curitiba, PR, Brasil. E-mail: fredericoaraujo.vet@gmail. com; monalisalukascek@hotmail.com; luci.laskoski@gmail.com; marimedvet@gmail.com

${ }^{2}$ Profs,. Dept ${ }^{\mathrm{o}}$ de Medicina Veterinária, UFPR, Curitiba, PR, Brasil. E-mail: deconto@ufpr.br; petriches@gmail.com

* Author for correspondence
} 
cesto de aço fixado com dois parafusos. Evidências de fusão foram obtidas por exames radiográficos periódicos durante seis meses de pós-operatório. O novo modelo de cesto de aço utilizado nessa cirurgia provou ser eficiente para descompressão e estabilização das vértebras, permitindo o desenvolvimento da artrodese e remissão dos sinais clínicos. A fixação do cesto com parafusos reduziu o risco de migração do implante.

Palavras-chave: Cavalo, cesto de aço, cirurgia de coluna, compressão medular, wobbler

\section{Introduction}

Cervical vertebral stenotic myelopathy (CVSM), also known as cervical ataxia or wobbler syndrome, is caused by narrowing of the medullary canal due to a malformation of the cervical vertebrae, instability and cervical compressive myelopathy (RUSH; GRADY, 2008). The compression can be intermittent or continuous, resulting in neurological alterations, and can affect the first cervical vertebral body (C1) through the first thoracic vertebral body (T1), with one to four points of stenosis (MOORE et al., 1993; NOUT; REED, 2003). Spinal cord compression can be caused by many factors, including bony malformations of the cervical vertebrae, misalignment between adjacent vertebrae, cranial extension of the dorsal lamina, distortion of the epiphyseal end plate and enlargement of the ligamentum flavum (NOUT; REED, 2003; VAN BIERVLIET et al., 2006). CVSM is most frequently observed in young horses between six months and four years of age, especially in male, rapidly growing Quarter Horse, Thoroughbred and Apaloosa breeds (RUSH, 2012). The main clinical signs are ataxia, hypermetria, weakness, and abnormal stance, delayed responses to proprioceptive positioning, with a commonly symmetrical manifestation that is more evident in the pelvic limbs. Cranial nerves do not present changes and mentation is normal (NOUT; REED, 2003; RUSH; GRADY, 2008). The first steps in diagnosis are the history of the animal, the clinical signs and a careful and complete physical and neurological examination. The most commonly used techniques to achieve a definitive diagnosis are myelography and the sagittal ratio measurement of the cervical vertebrae. A ratio below $52 \%$ for $\mathrm{C} 3$ through $\mathrm{C} 6$ and below $56 \%$ for $\mathrm{C} 6$ through $\mathrm{C} 7$ is indicative of vertebral foramen narrowing (NOUT; REED, 2003; RUSH, 2012; VAN BIERVLIET et al., 2006).

It is important to exclude other spinal diseases for spinal cord ataxia, such as equine protozoal myeloencephalitis, trauma, equine degenerative myeloencephalopathy or equine herpes virus myelitis in young horses (NOUT; REED, 2003; RUSH, 2012). There are treatments available, from conservative to surgical, with varying efficacy. Nevertheless, surgery is the most appropriate choice in the majority of cases because with quick and efficient decompression of the spinal cord, worsening lesions can be avoided. The surgical technique for arthrodesis most often cited in the literature uses a steel basket; other techniques include using a block or compression plate or dorsal laminectomy (MOORE et al., 1993; RUSH, 2012).

The aim of this case report is to present a surgical intervention using a modified steel basket technique for the treatment of equine cervical vertebral stenotic myelopathy in a Quarter Horse..

\section{Case Report}

A two-year-old Quarter Horse was referred to our hospital after presenting with ataxia six months prior without a history of trauma. The animal had been treated for equine protozoal myeloencephalitis with diclazuril and sulfadiazine for 60 days with no improvement in neurological signs.

During the initial examination, it was observed that the horse had grade 2 ataxia (MAYHEW et al., 1978) while walking and an absence of muscle 
atrophy; however, when the patient walked with the head elevated, the signs of ataxia worsened. A physical exam revealed normal heart and respiratory rates and sounds, a capillary refill time of 2 seconds and a rectal temperature of $38^{\circ} \mathrm{C}$. The complete blood count and chemistry panel were both normal. A neurological examination of the cranial nerves showed no abnormalities.

The patient was sedated with acepromazine $\left(0.05 \mathrm{mg} \mathrm{kg}^{-1}\right)$ and anesthetized (induction and maintenance) with xylazine $\left(0.5 \mathrm{mg} \mathrm{kg}^{-1}\right)$, ketamine $\left(2.2 \mathrm{mg} \mathrm{kg}^{-1}\right)$ and guaiacol glycerol ether (triple drip) $\left(50 \mathrm{~g} \mathrm{~L}^{-1}\right)$ to perform cerebrospinal fluid (CSF) collection and radiographs.

CSF collection was performed in the atlantooccipital space using a $14 \mathrm{G}$ catheter; the sample was sent to a laboratory for analysis and was tested for equine protozoal myeloencephalitis by western blot and equine herpes virus type I by viral isolation in tissue cell culture. CSF analysis showed no alterations and was negative for infectious diseases. The radiographs were taken at the level of the cervical vertebrae with the neck in a normal position and then immediately afterwards with a flexed neck. The interpretation of the radiographic films showed one point of stenosis of the spinal cord between $\mathrm{C} 3$ and $\mathrm{C} 4$, based on the sagittal intervertebral ratio measurements: $45 \%$ in the image with the neck in the neutral position (Figure 1A) and $40 \%$ in the image with neck in the flexed position (Figure 1B).

Based on these results, surgical treatment was chosen for decompression and arthrodesis of the stenotic point using a modified Cloward's technique (DEBOWES et al., 1984). The animal received acepromazine at $0.05 \mathrm{mg} \mathrm{kg}{ }^{-1}$ for sedation and midazolam $\left(0.1 \mathrm{mg} \mathrm{kg}^{-1}\right)$ and ketamine $\left(2.2 \mathrm{mg} \mathrm{kg}^{-}\right.$ $\left.{ }^{1}\right)$ for induction; anesthesia was maintained during surgery with isofluorane.

The patient was placed in a supine position with the neck extended, where it was shaved on the ventral region followed by antisepsis with degerming povidone-iodine $1 \%$, topical povidoneiodine and $70 \%$ ethanol, respectively. Needles were placed on the skin in the region of each vertebra, confirming by regional radiograph the location to be accessed. The procedure began with a longitudinal skin incision of approximately $20 \mathrm{~cm}$, followed by platysma muscle incision and divulsion of the omohyoid, sternohyoid and sternothyreoid muscles. The trachea was dissected in the dorsolateral direction, isolating the right vagosympathetic trunk. After identification of the ventral surface of the vertebrae (C3 and $\mathrm{C} 4)$ and their muscle attachments, debridement of these attachments was performed, releasing the ventral crest.

After osteotomy of the ventral crest, a perforation directed to the medullary canal was made using a $3 \mathrm{~mm}$ drill, $30 \mathrm{~mm}$ deep and perpendicularly to the vertebral body. Radiographic control was performed to confirm the drill tip location at the middle of the intervertebral disc. After this verification, the hole was expanded with a $6 \mathrm{~mm}$ drill, and then engaged using a cup saw $25 \mathrm{~mm}$ in diameter. This procedure introduced the saw to a maximum depth of $30 \mathrm{~mm}$, in order to stay 10 $\mathrm{mm}$ below to the ventral border of the medullary canal. To complete the drilling, a $25 \mathrm{~mm}$ drill shaped the final hole and removed any remaining bone material and intervertebral disc debris, i.e., a circular defect $25 \times 30 \mathrm{~mm}$ in depth was created between the cranial and caudal vertebrae. The metal basket was filled with bone extracted from previous drillings, and inserted into the hole, with the aid of a pin impactor and a hammer. To retain the basket in place, two perforations with a $25 \mathrm{~mm}$ drill were made in cranial and caudal directions, at an angle of $45^{\circ}$, passing through the basket bores and into the vertebral bone. Then, two $4.5 \times 32 \mathrm{~mm}$ screws were inserted, one in each bore, to achieve complete fixation of the basket. 
Figure 1. A - Myelographic with the neck in the neutral position, showing narrowing of $45 \%$ determined by minimum sagittal ratio. B - Radiograph with the neck in in the flexed position, showing narrowing of $40 \%$ determined by minimum sagittal ratio.
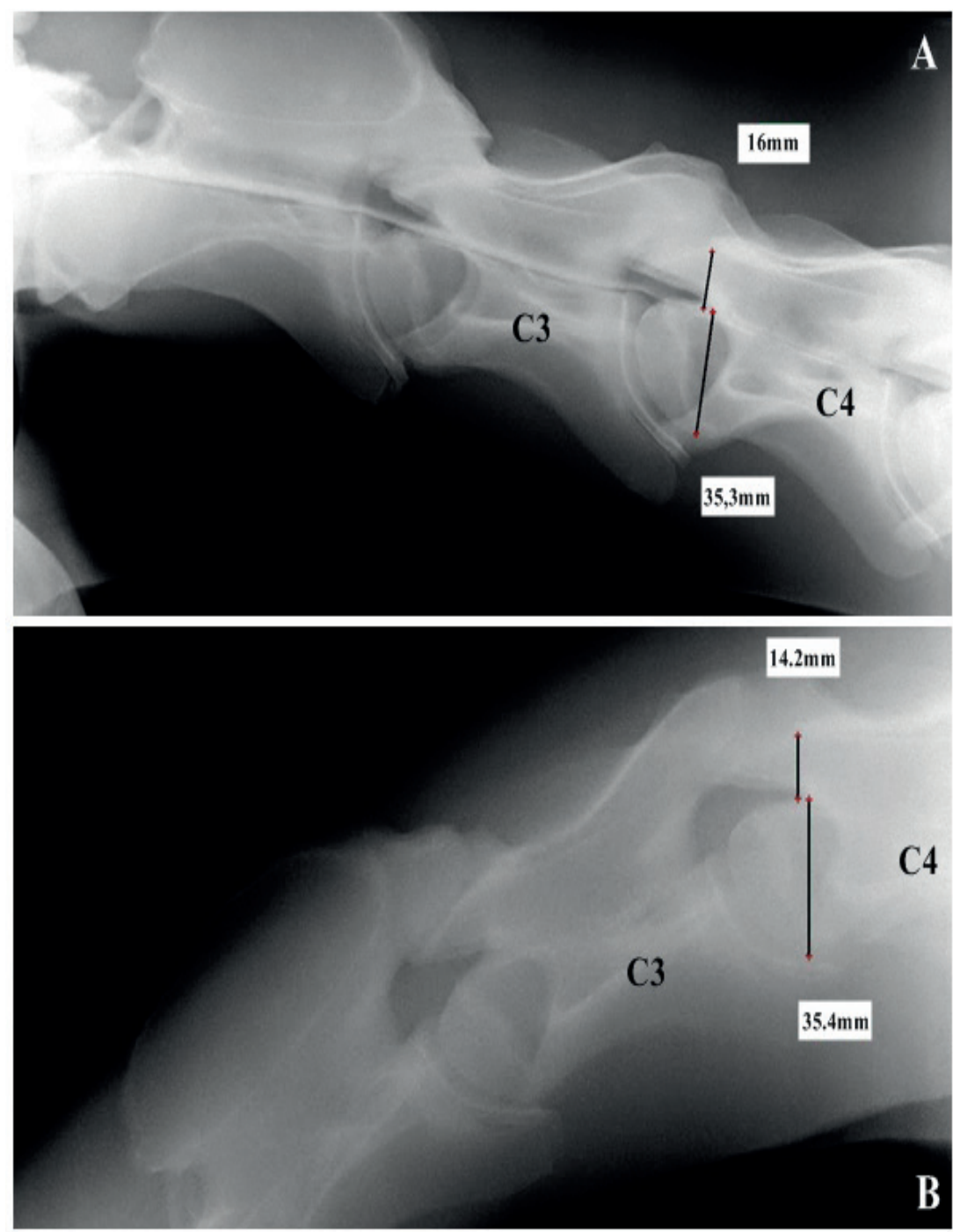

The platysma, omohyoid, sternohyoid and sternothyreoid muscles were sutured individually with simple interrupted stitches using $1 \mathrm{~mm}$ polyglactin 910, then subcutaneous suture were made with the same thread and the skin was sutured in a Wolf pattern with $1 \mathrm{~mm}$ nylon. Immediately after the surgery, radiography was performed to verify the position of the implant (Figure 2A).

Post-surgery, the animal was medicated with phenylbutazone (4.4 mg $\left.\mathrm{kg}^{-1}, \mathrm{IV}, \mathrm{BID}\right)$ and the antibiotic gentamicin (6.6 mg kg-1, IV, SID) for seven days, benzathine penicillin $\left(22,000 \mathrm{IU} \mathrm{kg}^{-1}\right.$, $\mathrm{IV}$, EOD) for six days, and metronidazole (15 mg $\left.\mathrm{kg}^{-1}, \mathrm{IV}, \mathrm{BID}\right)$ for seven days. Dressing and cleaning of the surgical wound was performed every day until healing was complete. Sutures were removed 12 days postoperatively. The animal was kept in restriction of movement, remaining in the stall for 90 days. 
Figure 2. Check radiography after arthrodesis surgery of $\mathrm{C} 3-\mathrm{C} 4$ by a steel basked modified technique of a horse with cervical vertebral stenotic myelopathy. A - immediately after surgery; B - ninety days after surgery, showing no infection and no implant migration; C - six months after surgery, showing intervertebral fusion.
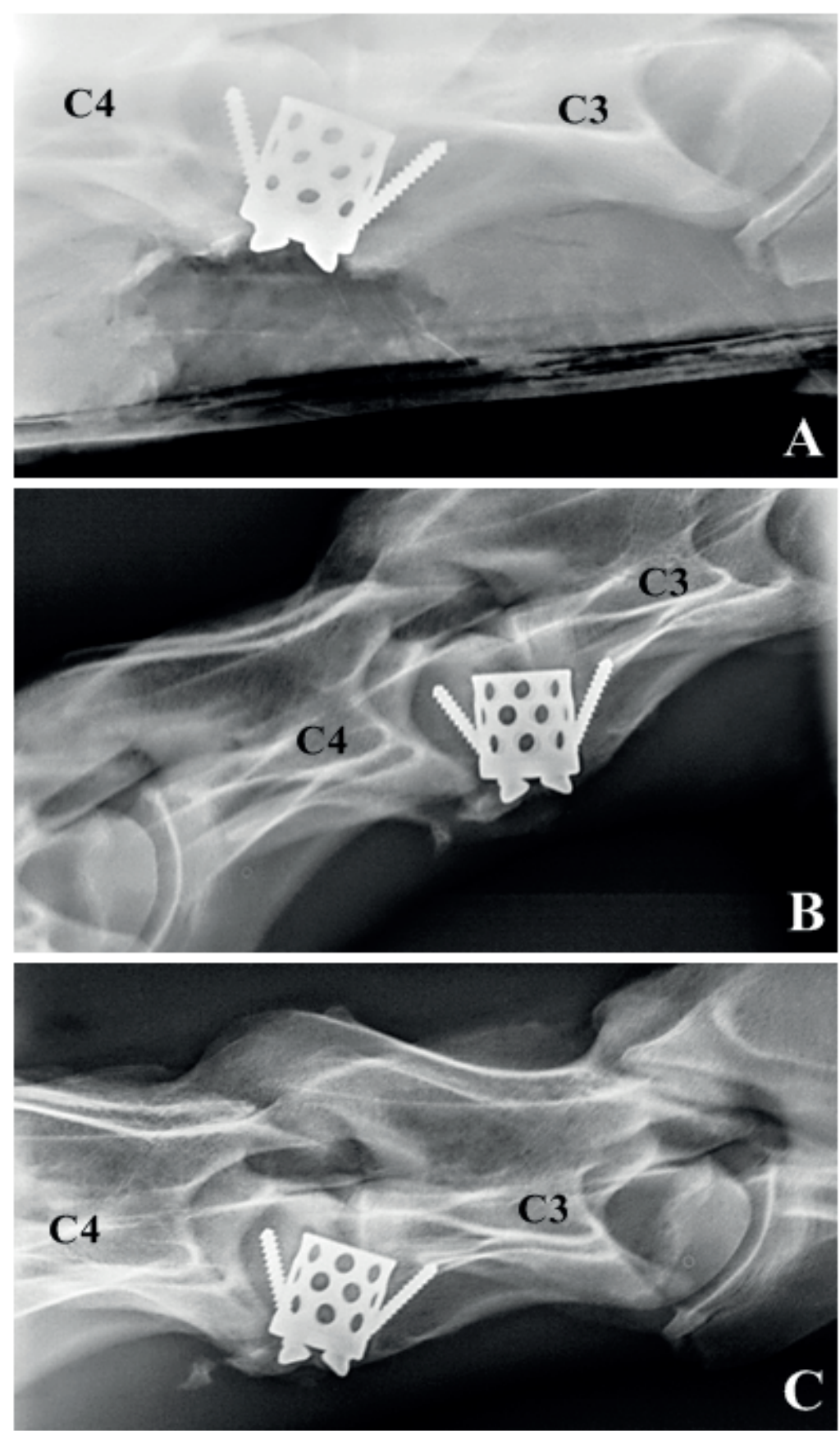

During four the weeks following surgery, the ataxia worsened by one grade, but improved gradually over a period of six months, after which the horse did not show any signs of ataxia. Cervical radiographs were taken at 20 and 90 days (Figure
2B) after the procedure to verify the implant position and intervertebral fusion and to check for possible infections or other complications. After four months of monitoring the patient, the animal showed a marked improvement in ataxia. New radiographs 
were taken at six months (Figure 2C) after surgery and showed surgical success. Radiographically, the steel basket was fixed at the same place as at the time of surgery, without signs of migration, and an increase radiopacity between vertebrae (C3-C4) was observed, showing consolidation on the joint line. The animal was adopted, and training was initiated. The coach reported that there were no limitations in work compared to other animals

\section{Discussion}

The animal in this study had many of the characteristics (Quarter Horse breed, young, and male) that have been described by Nout and Reed (2003), Moore et al. (1993) and other authors as predisposing characteristics for CVSM. The clinical signs of ataxia and the CSF analysis, which was negative for infectious disease, also corroborated a presumptive diagnosis of CVSM.

The cervical radiographs excluded fractures, osteoarthritis, bone infections and neoplastic masses and showed a stenotic point. Using the minimum sagittal ratio measurement cited by Van Biervliet et al. (2006), ratios of $45 \%$ with the neck extended and $40 \%$ with the neck flexed were observed, which are much smaller than the ratio of $52 \%$ cited by those authors and further supported the diagnosis of CVSM.

Myelography is the gold standard to detect cervical compression points; however, it could not be used in this animal due to the occurrence of a seizure after contrast administration, a result that can be expected in this exam (RUSH, 2012). Myelography is the most frequently used test to confirm the diagnosis of CVSM, though it may provide false-positive or false-negative results according to the interpretation of the contrast column (RUSH; GRADY, 2008). Janes et al. (2013) found that the minimal sagittal diameter intravertebral and intervertebral standard ratios may also provide a false-negative or false-positive diagnosis when compared with magnetic resonance imaging, due to the observed variation in the medullary canal format among animals. However, this variation is still able to provide adequate space for the spinal cord, even if a narrowing of the spinal canal is present. The animal may display a narrowing of the spinal canal without developing clinical signs. Even with its limitations, the intervertebral sagittal ratio measurement technique has a sensitivity and specificity of around $89 \%$ and can be used to help diagnose CVSM (RUSH, 2012).

Based on the history, clinical signs and radiographs, surgical treatment was chosen, although Nout and Reed (2003) and Rush and Grady (2008) described conservative treatment as producing better results in very young animals and in those with mild neurological deficits. Moore et al. (1993) and DeBowes et al. (1984) have stated that decompression and vertebral fusion through a surgical procedure is the best treatment, with a better prognosis for CVSM.

The choice of surgical technique used in this study was based on the publications of many authors, such as DeBowes et al. (1984) and Moore et al. (1993), who reported success when performing a modified Cloward's technique using a cylindrical cage (steel basket) in horses with different degrees of ataxia and with one or more points of stenosis between the cervical vertebrae. Additionally, DeBowes et al. (1984) demonstrated that the use of a packed cage with an autogenous bone graft assisted in the formation of a more stable bone fusion. This study also found good results using this method.

We used a steel packed basket integrated with an autogenous bone graft and two cortical screws to increase stability. Matthew et al. (2014), when studying human spine models, reported that a cage integrated with screws has the same biomechanical results as using an anterior plate with screws for fixation. Moreover, Kandziora et al. (2001), in his biomechanical study using cages in sheep spine models for interbody fusion, concluded that 
cylindrical cages control extension and flexion more effectively than screw cages with a screw design. Based on the results of the studies cited above, as well as Shimamoto et al. (2001) who suggested the use of an additional internal or external support integrated with a cage for better stabilization, we concluded that our modified technique could be used for the treatment of cervical vertebral stenosis.

After the surgery, the ataxia worsened to grade 3 , and only improved (to grade 2) 30 days later. We could not find any similar report by other authors; however, the nature of the surgical procedure might influence the postoperative inflammatory response, as shown by Jacobsen et al. (2009), causing swelling and increased pressure on the area, making it difficult to complete medullary recovery during the first days after surgery.

Four months after the surgery, the animal had improved greatly, with only mild ataxia. In the radiograph performed at this time, the implant presented good signs of consolidation with the cervical vertebrae. Six months later, the patient's ataxia improved to a grade 0 , a result observed by Moore et al. (1993) at the same time point in many horses of their study. We conclude that the technique of performing cervical arthrodesis with the use of a modified steel basket is effective for the correction of cervical stenotic myelopathy.

\section{References}

DEBOWES, R. M.; GRANT, B. D.; BAGBY, G. W.; GALLINA, A. M.; SANDE, R. D.; RATZLAFF, M. H. Cervical vertebral interbody fusion in the horse: a comparative study of bovine xenografts and autografts supported by stainless steel basket. American Journal of Veterinary Research, Schaumburg, v. 45, n. 1, p. 191199, 1984.

JACOBSEN, S.; NIELSEN, J. V.; KJELGAARDHANSEN, M.; TOELBOELL, T.; FJELDBORG, J.; HALLING-THOMSEN, M.; MARTINUSSEN, T.; THOEFNER, M. B. Acute phase response to surgery of varying intensity in horses: preliminary study. Veterinary Surgery, Davis, v. 38, n. 6, p. 762-769, 2009.
JANES, J. G.; GARRETT K, S.; MCQUERRY, K. J.; PEASE, A.; PWILLIAMS, N. M.; REED, S. M.; MACLEOD, J. N. Comparison of magnetic resonance imaging with standing cervical radiographs for evaluation of vertebral canal stenosis in equine cervical stenotic myelopathy. Equine Veterinary Journal, Ely, v. 46, n. 6, p. 681-686, 2013.

KANDZIORA, F.; PFLUGMACHER, R.; SCHÄFER, J.; BORN, C.; DUDA, G.; HAAS, N. P.; MITTLMEIER, T. Biomechanical comparison of cervical spine interbody fusion cages. Spine, Philadelphia, v. 26, n. 17, p. 18501857, 2001.

MATTHEW, I. S.; ANIRUDDH, N. N.; ROGER, B. G. A. F. C.; BRANDON, G. S.; ANTONIO, E. C. Biomechanics of an integrated interbody device versus ACDF anterior locking plate in a single-level cervical spine fusion construct. The Spine Journal, Maryland Heights, v. 14, n. 1, p. 128-136, 2014.

MAYHEW, I. G.; DE LAHUNTA, A.; WHITLOCK, R. H.; KROOK, L.; TASKER, J. B. Spinal cord disease in the horse. The Cornell Veterinarian, Ithaca, v. 68, p. 44105, 1978. Supplement 6.

MOORE, B. R.; REED, S. M.; ROBERTSON, J. T. Surgical treatment of cervical stenotic myelopathy in horses: 73 cases (1983-1992). Journal of the American Veterinary Medical Association, Schaumburg, v. 203, n. 1, p. 108-112, 1993.

NOUT, Y. S.; REED, S. M. Cervical vertebral stenotic myelopathy. Equine Veterinary Education, Ely, v. 15, n. 4, p. 212-223, 2003.

RUSH, B. R. Developmental vertebral anomalies In: AUER, J. A.; STICK, J. A. Equine surgery. $4^{\text {th }}$ ed. St. Louis, Missouri: Elsevier Saunders, 2012. p. 693-699.

RUSH, B. R.; GRADY, J. A. Cervical stenotic myelopathy. In: Marianne Tear. Compendium equine archive. [S.1.: s.n.], 2008. p. 430-436. Available at: $<$ http://vetfolio.com/ neurology/cervical-stenotic-myelopathy $>$. Accessed at: 10 jan. 2015.

SHIMAMOTO, N.; CUNNINGHAM,B. W.; DMITRIEV, E. A.; MINAMI, A.; MCAFEE, P. C. Biomechanical evaluation of stand-alone interbody fusion cages in the cervical spine. Spine, Philadelphia, v. 26, n. 19, p. 432436, 2001.

VAN BIERVLIET, J. V.; MAYHEW, J.; DE LAHUNTA, A. Cervical vertebral compressive myelopathy: diagnosis. Clinical Techniques in Equine Practice, Fort Collins, v. 5, n. 1, p. 54-59, 2006. 
